\title{
Ультразвуковой неразрушающий контроль структурной однородности композиционных материалов и конструкций на их основе
} УДК 620.179

\section{Ultrasonic non-destructive testing structural uniformity of composite materials and structures on their basis}

\section{Д. И. Чулков, А.В. Терехин, М.Е. Типикин}

АО «ОНПП «Технология» им. А.Г. Ромашина» ГНЦ РФ, Обнинск, Россия

\section{А. М. Думанский}

Институт машиноведения им. А. А. Благонравова РАН, Москва, Россия

Московский государственный технический университет имени Н. Э. Баумана, Москва, Россия
D. I. Chulkov, A. V. Terekhin, M. E. Tipikin

JSC «ORPE «Technologiya» named after A. G. Romashin», 249031 Obninsk, Russia

\section{A.M.Dumansky}

Mechanical Engineering Research Institute of Russian academy of sciences, Materials Sciences Department, Moscow, Russia Bauman Moscow State Technical University, Moscow, Russia

Поступила в редакцию 10.11.2021, принята к печати 15.11.2021

\section{Абстракт}

Представлены результаты экспериментальных работ по разработке методики неразрушающего контроля качества элементов тонкостенных конструкций летательных аппаратов из композиционных материалов ультразвуковым методом. Проведены экспериментально-теоретические исследования по обеспечению надёжности высоконагруженных элементов конструкций летательных аппаратов и проверка корректности разрабатываемой методики путём сопоставления результатов стендовых теплопрочностных испытаний с результатами неразрушающего контроля. Внедрение методики в производство позволило повысить надёжность ответственных элементов конструкций летательных аппаратов.

\section{Abstract}

The results of experimental work on the development of a technique for non-destructive quality control of elements of thin-walled structures of aircrafts made of composite materials by the ultrasonic method are presented. Experimental and theoretical studies have been carried out to ensure the reliability of highly loaded elements of aircraft structures and to check the correctness of the developed technique by comparing the results of bench thermal strength tests with the results of non-destructive testing. The implementation of the method allowed enhancing the safety of aircraft structural elements.

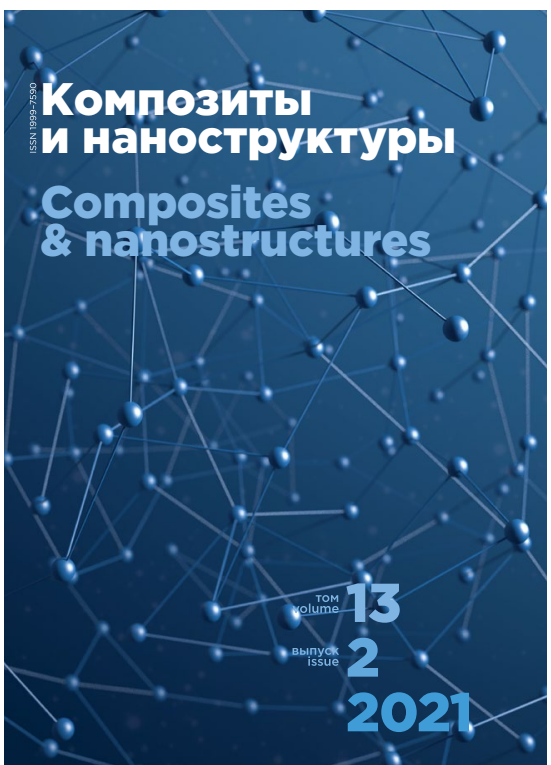

